\title{
The effectiveness of community-based interventions to improve maternal and infant health in the Northeast of Brazil
}

\author{
Alan Emond, ${ }^{1}$ Jon Pollock, ${ }^{1}$ Nilma da Costa, ${ }^{2}$ Técia Maranhão, ${ }^{2}$ and Albanita Macedo ${ }^{2}$
}

ABSTRACT Objective. To evaluate the effectiveness of a community-based intervention project aimed at reducing maternal and infant mortality in a poor urban district in the city of Natal, in the Northeast of Brazil.

Methods. The intervention, called the ProNatal project, introduced a program of integrated community health care to a geographically defined population. The interventions included the establishment of antenatal clinics at the district's health centers, the opening of the maternity facilities at the polyclinic for low-risk deliveries, the introduction of a family planning clinic and a breast-feeding clinic, support from pediatricians for under-5 (well-baby) clinics, children's outpatient services and children's emergency care, and the introduction of health agents recruited from the local community. Representative surveys of the population were taken at the project's inception (July 1995) and then 30 months later (December 1997), using a general health questionnaire adapted to the local conditions. Mortality data were collected from local registration systems as well as from an autopsy survey of perinatal and infant deaths.

Results. During 1995 there were 4 maternal deaths from 1195 pregnancies (maternal mortality of 335/100 000); three of the deaths were related to hypertension and one to uterine perforation after an illegal abortion. During 1998 (post-intervention), there were no maternal deaths in pregnancy or childbirth. In 1993 no deliveries took place at the polyclinic, but in 1998 there were 946 deliveries at the clinic without any serious complications. The method of delivery, the incidence of prematurity, and the incidence of low birthweight did not change significantly over the study period. In the post-intervention survey, 75\% of women reported receiving contraceptive advice from a doctor in the preceding year, compared to $50 \%$ in the first sample. A mortality survey carried out in 1993-1995 estimated the infant mortality rate to be 60/1 000 live births. By 1998, using data collected locally by active surveillance, the infant mortality rate was 37/1 000 live births. The causes of infant death in both those periods were dominated by respiratory infections and diarrheal disease. Over $95 \%$ of both samples initiated breast-feeding, but a higher proportion of the post-intervention sample reported breast-feeding for longer than 6 months ( $41 \%$ vs. $32 \%, \mathrm{P}=0.0005)$. No differences were apparent in the use of under-5 clinics, but immunization rates improved. Post-intervention, significant improvements were documented in the mothers' understanding of basic hygiene, their knowledge of causes of common diseases, and their management of acute respiratory infections and diarrhea in children. This was particularly true for the households visited by a community health agent. Conclusions. Inequalities in health care in poor urban populations can be reduced by integrated community-based interventions, including the use of health agents recruited from the local community.

Key words Delivery of health care, primary health care, infant mortality, maternal mortality, Brazil.

1 University of Bristol, Institute of Child Health, Bristol BS2 1AE, United Kingdom. Send correspondence to: Alan Emond, Institute of Child
Health, Education Centre, Upper Maudlin Street, Bristol BS2 1AE, United Kingdom; fax: 0044117 342 0178; e-mail: alan.emond@bristol.ac.uk
2 Universidade Federal do Rio Grande do Norte, Centro das Ciências da Saúde, Rua Cordeiro de Farias, Petrópolis, 59012-300 Natal RN, Brazil. 
The Northeast of Brazil is one of the poorest parts of that country, with high indices of mortality and morbidity and poorly developed health services (1). The ProNatal project has been a collaborative initiative to improve maternal and child health in the city of Natal, in the state of Rio Grande do Norte. The principal project collaborators were the Federal University of Rio Grande do Norte (FURGN), the municipal secretariat of Natal, the state health secretariat of Rio Grande do Norte, and the University of Bristol (United Kingdom). The idea for the project originated in 1991 from obstetricians and pediatricians at the FURGN, who recognized the high maternal and infant mortality in the western part of Natal and formed a partnership with the Institute of Child Health at the University of Bristol to bring about change in the community. Funding was secured from the Brazilian and United Kingdom Governments in 1993, training commenced in 1994, and the intervention took place between 1995 and 1997. Many of the activities are continuing, and an active link still exists between Bristol and Natal supporting the training of nurse-midwives. The project was designed from the outset as a "model project," the lessons of which could be transferred elsewhere within the Northeast of Brazil.

Natal is the capital of the state of Rio Grande do Norte and has a population of some 700 000. Community health care in Natal is traditionally managed as a number of individual services (municipal health clinics, state-run health centers, and charitable agencies), with poor coordination and organization among them.

The ProNatal project defined an area in the western part of Natal, the district of Felipe Camarão, as the study population. The project was intended to reduce maternal and infant mortality in the district by introducing an integrated structure of community health care. Secondary objectives included promoting the population's awareness of health issues and encouraging them to use preventative and primary health care services in Felipe
Camarão. Another secondary objective was to stimulate the growth of an evaluative culture amongst health professionals, with them using communitybased health information to assess the health needs of the population.

The district of Felipe Camarão is on the western edge of Natal, $8 \mathrm{~km}$ from the center of the city. The district is contained on one side by sand dunes and on the other by a river. The 42000 residents live in approximately 6000 houses, with a population density of 663 inhabitants/hectare. The population is largely of mixed race and is socioeconomically deprived, with high levels of unemployment and poor community facilities such as shops, meeting rooms, and recreational and sports facilities. The community is served by two health centers. One is a basic municipal health post that provides outpatient services, and the other is a state polyclinic with obstetric facilities and a small emergency department. When the project was planned in 1993, the polyclinic was barely functioning and no women were giving birth there. Although the exact maternal and infant mortality rates were unknown, data from hospitals in the city suggested that mortality and morbidity were particularly high among residents of Felipe Camarão. Initial studies of maternal, perinatal, and infant mortality in the study population were undertaken in 1993-1995 (2). We now report the effects on the health of this community of subsequent interventions implemented from 1995 through 1997.

\section{METHODOLOGY}

At the beginning of the project in 1993 the project staff sought the support of local community leaders. Several meetings were held to seek people's views on ways in which their health could be improved and also to inform the population of the project's proposed interventions. Members of the ProNatal project team from the Federal University of Rio Grande do Norte (FURGN) and from the University of Bristol provided training for doctors, nurses, and social workers at the two health centers. Subsequent interventions associated with the ProNatal project were multifaceted.

One intervention was the establishment of antenatal clinics at the two Felipe Camarão health centers. These took place twice a week with FURGN medical staff (obstetricians and trainee residents). Women attending the community antenatal clinics were assessed as high or low risk according to age, parity, previous obstetric history, nutritional status, anemia, and blood pressure. High-risk pregnancies were booked for delivery at the Januário Cicco maternity hospital (JCMH), which is $8 \mathrm{~km}$ from Felipe Camarão. Low-risk mothers were offered delivery at the polyclinic in Felipe Camarão. In addition, special health promotion classes for pregnant women were run weekly by social workers from the health centers, who also made a limited number of home visits.

A second intervention was the opening of the maternity facilities at the polyclinic for low-risk deliveries. This commenced gradually from 1995, staffed by a junior obstetrician and, from 1997 onwards, by nurse-midwives.

A third intervention was the introduction of a family planning clinic, linked to services at JCMH and provided on a weekly basis by a gynecologist from FURGN who was supported by trainee residents from the FURGN Department of Obstetrics and Gynecology.

A fourth intervention was the introduction of a breast-feeding clinic at the health center, to promote breast-feeding and to support women having difficulties feeding an infant. This was staffed by a pediatrician from FURGN and by nurses and social workers from the health centers.

A fifth intervention was the consolidation and support of existing children's services in the community, including under-5 (well-baby) clinics, children's outpatient services, and children's emergency care. This was provided by specialist pediatricians from the FURGN Department of Pediatrics, in support of general pediatri- 
cians employed by the municipal health secretariat.

A sixth intervention was the introduction of community health agents, each one covering 200 families. (Due to financial constraints, this was only achieved for the part of Felipe Camarão close to the basic health post, covering $43 \%$ of the study population. Nevertheless, this allowed a comparison to be made between families assigned a health agent and those who were not.) The community health agents conducted home visits, seeing each family at least once a month. Their visits dealt with specific healthpromotion topics, including promotion of breast-feeding, causes and management of diarrheal and respiratory diseases, and prevention of infection by HIV and other diseases. The health agents also actively sought out and encouraged pregnant women to attend antenatal clinics, parents to take their infants for immunization and wellbaby clinics, and hypertensive adults to go for monitoring and treatment.

The seventh intervention was the teaching in the community clinics of public health and pediatrics to medical and nursing students from the FURGN. In addition, the training of residents in obstetrics, pediatrics, and public health was devolved from the medical school to the Felipe Camarão community clinics. The residency training program was restructured to include rotation through the community clinics, and the project team tried to encourage doctors and nurses working in the community to develop an evaluative culture by adopting a more critical approach to practice. A concerted effort was put into the training of the clinical staff at the Januário Cicco maternity hospital in practicing baby-friendly policies $(3,4)$, and the JCMH was awarded babyfriendly status by the United Nations Children's Fund in 1994.

In order to evaluate these interventions and also due to the lack of local population-based health data, we undertook representative surveys of the population in July 1995 and also after the project had been running for two and a half years, in December 1997. A general health questionnaire adapted to the local conditions was developed. It included sections on demographic background, reproductive history, health history of women and children in the family, acute and chronic diseases, attitudes toward health, health behavior, and use of local health services. Following piloting in 100 households in December 1994, a modified version of the questionnaire was applied to representative samples of the community in July 1995, and again in December 1997. On each occasion, the sample was selected by dividing Felipe Camarão into geographical sectors, using detailed maps provided by Brazilian Institute of Geography and Statistics (5).

On the first (pre-intervention) survey the interviewer responsible for each sector applied the questionnaire in face-to-face interviews in every fifth house, in a total of 1082 homes. The second (post-intervention) survey was done in every tenth house, in a total of 600 homes. The interviewee was the oldest woman of the household between 15 and 45 years of age. In a few houses men or old women were living on their own, and the interviewers moved on to the next house on the street. The response rate (valid, complete questionnaires) was $87 \%$ in the pre-intervention survey and just under $100 \%$ in the post-intervention one.

The questionnaire data were processed using two software packages. The data were initially cleaned and organized using Epi Info 6 (United States Centers for Disease Control and Prevention, Atlanta, Georgia), and then they were analyzed using SPSS-PC (Statistical Package for the Social Sciences Inc, Chicago, Illinois, United States). Initial analysis was univariate; subsequently, derived variables were created. Other data were collected from clinic records at the health centers and at the Januário Cicco referral maternity hospital. Information on birthweight, gestation, and basic details of deliveries was abstracted from the Natal municipal birth registration system. This municipal database relied on forms returned from local hospitals and polyclinics, and it did not necessarily include details on home deliveries. Only women with an address in Felipe Camarão were included in our data abstraction. Data on immunizations were obtained from clinic returns to the municipal health department in Natal.

\section{RESULTS}

\section{Study population}

The first, pre-intervention survey interviewed 1082 women, but 160 questionnaires had to be rejected because of missing data, resulting in a final sample of 922 households. The second, post-intervention survey included 600 interviews, and the final sample was 599 households. The sample chosen for the second survey did not differ significantly from the first in demographic characteristics (Table 1).

The population is generally a stable one, with $60 \%$ having lived in Felipe Camarão for more than 5 years. Although the majority of households contained two parents living with their children, about one in five of the households consisted of a woman heading a single-parent family.

Educational levels were low, with four out of ten of the women not having completed primary education and fewer than one in ten with any secondary education. Most women were housewives, and $32 \%$ of their husbands were unemployed, according to the first survey. In a country with limited social assistance programs, this high level of unemployment contributed to the significant level of poverty found in the district. For example, $38 \%$ of mothers reported in the first survey that they did not have enough money to buy shoes for their children.

Most of the houses were made of cement blocks with corrugated iron or tile roofs and were connected to the municipal electrical system and water supply. Around 35\% were connected to the municipal sewage system, with the remainder using septic tanks. Most 
TABLE 1. Characteristics of study-population households, according to pre-intervention survey (July 1995) and post-intervention survey (December 1997), Felipe Camarão, Brazil

\begin{tabular}{lcc}
\hline & $\begin{array}{c}\text { Pre-intervention } \\
\text { (922 valid questionnaires) }\end{array}$ & $\begin{array}{c}\text { Post-intervention } \\
\text { (599 valid questionnaires) }\end{array}$ \\
\hline $\begin{array}{l}\text { Household composition } \\
\text { Adults (median) }\end{array}$ & 2 (range 1-6) \\
Children (median) & 2 (range 0-7) & 2 (range 1-5) $1-6)$ \\
$\quad$ Children < 5yrs (no., \% of households) & $510(55)$ & $305(51)$ \\
Housing tenure (no., \%) & & $479(80)$ \\
$\quad$ Owned & $716(78)$ & $120(20)$ \\
Rented & $206(22)$ & $545(91)$ \\
Facilities of the house (no., \%) & & $547(91)$ \\
$\quad$ Electricity & $813(88)$ & $209(35)$ \\
Piped water & $848(92)$ & $269(45)$ \\
Municipal sewage connection & $364(39)$ & $359(60)$ \\
Refrigerator & $378(41)$ & $120(20)$ \\
Marital status (no., \%) & & $120(20)$ \\
$\quad$ Married couple & $555(60)$ & \\
Single parent & $158(17)$ & $257(43)$ \\
Other/not specified & $209(23)$ & $221(37)$ \\
Educational level of woman interviewed (no., \%) & & $30(5)$ \\
Did not complete primary school & $382(41)$ & $91(15)$ \\
Completed primary school & $322(35)$ & $210(35)$ \\
Attended any secondary school & $64(7)$ & \\
Not given & $154(17)$ & \\
Employment of woman interviewed (no., \%) & $350(38)$ & \\
Works outside the home & & \\
\hline
\end{tabular}

Source: ProNatal questionnaires.

families lived within a 20-minute walk of one of the health centers, and only $2 \%$ had private means of transportation such as a motorcycle, bicycle, or horse.

\section{Maternal health}

Mortality. During 1995, there were 4 recorded maternal deaths associated with pregnancy and childbirth in residents of Felipe Camarão, out of a total of 1195 pregnancies (equivalent to a maternal mortality rate of 335/100 000), according to data from records at the maternity hospital and at the community clinics. The official maternal mortality rate in Natal at this time was 40/100 000. Three of those four Felipe Camarão maternal deaths were related to hypertension, and one to uterine perforation after an illegal abortion. In one of the cases of severe eclampsia, the infant was delivered stillborn by cesarean section prior to the death of the mother. There were 12 other deaths cant reduction compared to 1995 ( $P=$ 0.001, Fisher's exact test). Eight women between 15 and 45 years of age from Felipe Camarão died in 1998 due to other causes, including road traffic accidents, neoplasms, and HIV / AIDS or other infections.

Reproductive health. The two samples of women we interviewed did not in general differ in their past reproductive history, in terms of either outcome or use of health services. With regard to their most recent pregnancy before the respective survey, the rates of miscarriage, termination, and stillbirth were almost identical; however, the proportion of live births increased and the rate of early neonatal deaths decreased (Table 2). (It was not clear from the responses whether the most recent pregnancy had concluded during the intervention period of 19951997 or before this period.)

The number of births to residents of Felipe Camarão remained constant at between 1100 to 1250 per year during the project, but the numbers taking place at the polyclinic increased steadily. In 1993 there were no deliveries at the polyclinic, but there were 946 in 1998, with 620 being to women residents of Felipe Camarão. Although 7 women had to be transferred by ambulance from the polyclinic to JCMH in 1998, there were no major complications associated with delivery at the

TABLE 2. Outcome of pregnancy, in absolute figures and percentages, among women residents of Felipe Camarão, Brazil, 1995-1998

\begin{tabular}{lcc}
\hline & Pre-intervention & Post-intervention \\
\hline $\begin{array}{l}\text { Most-recent pregnancy } \\
\text { Stillbirth/miscarriage }\end{array}$ & $(n=922$ households $)$ & $(n=599$ households $)$ \\
Live births & $101(11)$ & $53(9)$ \\
Early neonatal deaths & $679(74)$ & $536(89)$ \\
Recorded births ${ }^{b}$ & $30(44 / 1000$ live births $)$ & $3(6 / 1000$ live births $)$ \\
Prematurity $(<37$ wks $)$ & $(n=1195)$ & $(n=1225)$ \\
Low birthweight $(<2.5 \mathrm{~kg})$ & $72(6)$ & $85(7)$ \\
Cesarean section & $96(8)$ & $98(8)$ \\
Community clinic delivery & $215(18)$ & $620(51)$ \\
\hline a Data are from ProNatal questionnaires of July 1995 and of December 1997. Due to missing data, the various \\
categories for most-recent pregnancy do not add to the respective $n$ value or to 100\%. \\
bata are from the Natal birth registration system for the years 1995 and 1998.
\end{tabular}


TABLE 3. Contraceptive use among women in study-population households, Felipe Camarão, Brazil, according to pre-intervention survey (July 1995) and post-intervention survey (December 1997)

\begin{tabular}{|c|c|c|c|c|c|c|c|c|}
\hline & \multicolumn{2}{|c|}{ Pre-intervention ${ }^{\mathrm{a}}$} & \multicolumn{2}{|c|}{ Post- intervention } & \multirow[b]{2}{*}{ Relative risk } & \multirow{2}{*}{$\begin{array}{l}95 \% \text { confidence } \\
\text { interval }\end{array}$} & \multirow[b]{2}{*}{$\chi^{2}$} & \multirow[b]{2}{*}{$P$} \\
\hline & No./n & $\%$ & No./n & $\%$ & & & & \\
\hline Received advice from doctor & $446 / 895$ & 50 & $444 / 594$ & 75 & 1.50 & $1.38-1.63$ & 92.2 & $<0.0001$ \\
\hline Tubal ligation & $305 / 889$ & 34 & $247 / 598$ & 41 & 1.20 & $1.06-1.37$ & 7.5 & 0.006 \\
\hline Hysterectomy & $37 / 878$ & 4 & $32 / 596$ & 5 & 1.27 & $0.80-2.02$ & 1.06 & 0.3 \\
\hline Correct understanding of fertile period & $353 / 888$ & 40 & $282 / 599$ & 47 & 1.18 & $1.05-1.33$ & 7.85 & 0.005 \\
\hline
\end{tabular}

Source: ProNatal questionnaires.

polyclinic during that year. The incidences of birth by cesarean section, of prematurity, and of low birthweight in infants born to residents of Felipe Camarão did not noticeably change during the period of the study (Table 2).

There were no differences reported in the two surveys in the incidence of gynecological problems or sexually transmitted diseases.

Before the establishment of community family planning clinics, the most popular place for women from Felipe Camarão to obtain contraception was a local pharmacy (to buy the Pill), but in the post-intervention survey $71 \%$ of respondents said they would use the service from the health centers. In the post-intervention sample, $75 \%$ reported having received contraceptive advice from a doctor in the preceding year, compared to $50 \%$ in the earlier sample (Table 3). Although the proportion of women using contraceptives (Pill, condom, intrauterine device) on a regular basis did not improve, the proportion of women who had undergone tubal ligation increased, from $34 \%$ in the first survey to $41 \%$ in the second.

Cervical screening, which is recommended in Natal but for which women are not specifically contacted and asked to make an appointment for such screening, did increase in frequency. Sixteen percent in the pre-intervention sample reported a screening examination in the preceding 12 months, rising to $27 \%$ in the post-intervention sample.

Attendance at antenatal clinics (seven visits recommended during a normal pregnancy) increased between 1995
TABLE 4. Attendance at antenatal clinics among women in Felipe Camarão, Brazil, 1995 births vs. 1998 births

\begin{tabular}{|c|c|c|c|c|}
\hline \multirow{2}{*}{$\begin{array}{l}\text { Number of } \\
\text { consultations } \\
\text { during } \\
\text { pregnancy }\end{array}$} & \multicolumn{2}{|c|}{1995 births } & \multicolumn{2}{|c|}{1998 births } \\
\hline & No. & $\%$ & No. & $\%$ \\
\hline 0 & 48 & 4.0 & 73 & 6.0 \\
\hline $1-6$ & 418 & 35.0 & 664 & 54.2 \\
\hline$\geq 7$ & 263 & 22.0 & 430 & 35.1 \\
\hline Not known & 466 & 39.0 & 58 & 4.7 \\
\hline Total & 1195 & 100.0 & 1225 & 100.0 \\
\hline
\end{tabular}

Source: Natal municipal birth registration system.

and 1998 (Table 4), but the change was not statistically significant.

In the post-intervention sample, $37 \%$ of women reported using the facilities of one of the local health centers in Felipe Camarão during the previous month, compared to $6 \%$ in the first sample. The two reasons most often cited in the second survey for a visit to the health center were a preventative (screening) visit $(21 \%)$ or a routine consultation $(20 \%)$.

Health behavior and attitudes to health. Breast-feeding rates were measured in two ways: 1) by asking all the mothers if they were currently breast-feeding and how long they intended to continue, and 2) if they were not currently breast-feeding, by asking them for how long they had fed their last infant. At the time of interview, $178(19 \%)$ of the first sample and 86
$(16 \%)$ of the second were breast-feeding (difference not significant), and the majority (over $70 \%$ in both groups) of the breast-feeding mothers stated that they were intending to continue for 6-12 months.

When asked about their last infant, $82 \%$ of the first sample and $100 \%$ of the second had done some breast-feeding (Table 5). The most common length of breast-feeding was 3-6 months, but a higher proportion of the post-intervention sample reported breast-feeding for longer than 6 months.

There were some important changes in the respondents' understanding of health issues. One survey question asked, "What is the most important way to avoid diseases in the home?" The most common response in the first survey was "to clean the house" $(46 \%)$, followed by "personal hygiene" (28\%) and "I don't know" (15\%). In the second survey the most frequent responses to that same question were: "personal hygiene" (34\%), "boil water" $(22 \%)$, and "cook food properly" $(17 \%)$. It is probable that the influence of the community health agents was significant in this area of health promotion. For example, 25\% of the households that received visits from the agents cited "boil water," compared to $14 \%$ of households who hadn't had an agent visit $\left(\chi^{2}=23.1, P=0.001\right)$. The respondents' understanding of the cause of coughs and colds did not differ significantly between the two samples, but the action taken with a child who has a cough for 3 days did change (Table 5). 
TABLE 5. Health behavior and attitudes of study-population women in community-based interventions to improve maternal and infant health in Felipe Camarão, Brazil, according to pre-intervention survey (July 1995) and post-intervention survey (December 1997)

\begin{tabular}{|c|c|c|c|c|c|c|c|c|}
\hline & \multicolumn{2}{|c|}{$\begin{array}{l}\text { Pre-intervention } \\
\quad(n=922)\end{array}$} & \multicolumn{2}{|c|}{$\begin{array}{l}\text { Post-intervention } \\
\quad(n=599)\end{array}$} & \multirow[b]{2}{*}{ Relative risk } & \multirow{2}{*}{$\begin{array}{l}95 \% \text { confidence } \\
\text { interval }\end{array}$} & \multirow[b]{2}{*}{$x^{2}$} & \multirow[b]{2}{*}{$P$} \\
\hline & No. & $\%$ & No. & $\%$ & & & & \\
\hline \multicolumn{9}{|l|}{ Last infant } \\
\hline Initiated breast-feeding & 756 & 82 & 599 & 100 & 1.22 & $1.18-1.26$ & 121.1 & $<0.0001$ \\
\hline Breast-feeding $>6$ months & 299 & 32 & 247 & 41 & 1.27 & $1.11-1.45$ & 12.24 & 0.0005 \\
\hline Cigarette smoking & 286 & 31 & 180 & 30 & 0.97 & $0.83-1.13$ & 0.16 & 0.69 \\
\hline \multicolumn{9}{|l|}{ Child with cough for 3 days } \\
\hline Take to doctor & 498 & 54 & 503 & 84 & 1.55 & $1.45-1.67$ & 144.9 & $<0.0001$ \\
\hline \multicolumn{9}{|l|}{ Child with diarrhea for 2 days } \\
\hline Give oral rehydration salts & 378 & 41 & 288 & 48 & 1.17 & $1.05-1.31$ & 7.4 & 0.006 \\
\hline Give other medicines & 65 & 7 & 6 & 1 & 0.14 & $0.06-0.33$ & 29.9 & $<0.0001$ \\
\hline Take to clinic/doctor & 360 & 39 & 305 & 51 & 1.30 & $1.17-1.46$ & 20.8 & $<0.0001$ \\
\hline
\end{tabular}

Source: ProNatal questionnaires.

Another survey question asked, "What causes diarrhea?" The proportion of respondents citing contaminated water increased from $44 \%$ to $70 \%$, the proportion mentioning contaminated food increased from $11 \%$ to $15 \%$, and the proportion listing worms as an explanation decreased from $13 \%$ to $2 \%$. The mothers' reported behavior with a child who has diarrhea for 2 days also changed between the pre-intervention and post-intervention samples, with an increase in the use of oral rehydration fluids and the use of primary health care (Table 5). These responses were again positively associated with whether or not a community health agent visited the home $\left(\chi^{2}=\right.$ $11.9, P=0.01$ ).

The proportion of women in the two samples who knew about AIDS increased from $64 \%$ in the first sample to $85 \%$ in the second. When asked, "How do you get AIDS?", the response "having sex with an infected person" increased from $36 \%$ to $46 \%$, "having sex without a condom" increased from $1 \%$ to $26 \%$, and "from contaminated blood" remained the same, at $15 \%$. The correct responses for sexual transmission were cited by 208/249 (84\%) of women whose households had health promotion input from a community health agent, and 224/350 (64\%) of those who didn't $\left(\chi^{2}=31.6, P=0.001\right)$.

\section{Child health}

Infant mortality. Determining an accurate infant mortality rate in the Felipe Camarão population proved difficult, principally because of the underregistration of infant deaths. The initial mortality survey (2) carried out in 1993-1995 determined the rate of underregistration of infant deaths to be $40 \%$. Allowing for this, an estimated true infant mortality rate was 60/1 000 live births for that 1993-1995 period. By 1998 more accurate figures were available because of active surveillance provided by the community health agents and social workers from the two health centers. Using data collected locally by this active surveillance, 43 deaths were identified in 1998 from a population of 1150 infants under 1 year of age, resulting in an infant mortality rate of $37 / 1000$ live births. It is likely therefore that infant mortality had declined over the time period of the study. The causes of infant death remained much the same, dominated by respiratory infections and diarrheal disease.

Childhood morbidity. The first, preintervention community survey collected information on the health status of 1956 children under 16 years of age, and the second, post-intervention survey collected similar data on 1220 children. The respondents were asked about problems experienced by children in the house during the previous month and also during the previous year prior to the interview. Overall, there were no significant differences in the morbidity profile provided by the two surveys.

Combining the results of the two surveys, respiratory infections were the most common illness reported in the previous month, affecting $46 \%$ of children $(53 \%$ of the ones under 5$)$. Vomiting and diarrhea lasting more than 2 days was reported to affect $16 \%$ of children (31\% of those under 5) during the previous month. Families with children under 5 had twice the incidence of respiratory infections, and three times the incidence of episodes of diarrhea when compared to families without such young children. Domestic or road traffic accidents were reported as having affected $1.4 \%$ of children in the previous month. Notifiable diseases, including measles, mumps, and chickenpox, were probably underreported, as only $8 \%$ of children were said to have had an infection in the previous year.

The most common chronic conditions affecting children in the preceding 12 months were skin infections 
TABLE 6. Immunization rates among children of households in Felipe Camarão, Brazil, who were born in 1995 and 1997

\begin{tabular}{|c|c|c|c|c|c|c|c|c|}
\hline & \multicolumn{2}{|c|}{$\begin{array}{l}1995 \text { births } \\
(n=1195)\end{array}$} & \multicolumn{2}{|c|}{$\begin{array}{l}1997 \text { births } \\
(n=1210)\end{array}$} & \multirow[b]{2}{*}{ Relative risk } & \multirow{2}{*}{$\begin{array}{c}95 \% \text { confidence } \\
\text { interval }\end{array}$} & \multirow[b]{2}{*}{$\chi^{2}$} & \multirow[b]{2}{*}{$P$} \\
\hline & No. & $\%$ & No. & $\%$ & & & & \\
\hline Polio (x 3) & 579 & 48 & 658 & 54 & 1.13 & $1.01-1.19$ & 5.27 & 0.02 \\
\hline DTP (x 3) & 735 & 62 & 784 & 65 & 1.05 & $0.97-1.09$ & 0.81 & 0.37 \\
\hline Measles (x 1) & 621 & 52 & 877 & 72 & 1.38 & $1.28-1.45$ & 91.0 & $<0.0001$ \\
\hline $\mathrm{BCG}(\mathrm{x} 1)$ & 908 & 76 & 1125 & 93 & 1.22 & $1.17-1.25$ & 115.7 & $<0.0001$ \\
\hline
\end{tabular}

Source: Natal municipal health department.

$(14 \%)$ and asthma (11\%). Chronic physical disabilities, including motor impairments, learning difficulty, and visual and auditory impairments were reported in $4 \%$ of children.

Use of preventative health services. Immunization rates, for which data were collected by the municipal health secretariat, rose during the period of the ProNatal project (Table 6). The improvements in immunization rates were particularly noticeable for BCG and measles. The coverage rates for both of those in Felipe Camarão in 1997 were also above the 1996 averages for the Northeast of Brazil as a whole: $93 \%$ vs. $59 \%$ for BCG, and $72 \%$ vs. $68 \%$ for measles.

Attendance at under-5 (well-baby) clinics was assessed in each survey, but unfortunately the responses were not precise enough to draw conclusions about coverage rates. In addition, because no birth register existed at either clinic, nor was it possible to calculate the coverage rates of the under- 5 population by using the clinic records.

\section{DISCUSSION}

The ProNatal project has attempted to improve maternal and infant health in a poor community in the Northeast of Brazil by applying a variety of community-based interventions, utilizing few new resources. The interventions have had to be made in a constantly changing political reality, with there being eight different municipal secretaries of health between 1993 and 1998, so sustaining change has always been the biggest challenge. Constant effort was required to persuade and encourage doctors from university departments to undertake the "extension" work needed for the project, providing both a clinical service and teaching students in the community. The students and residents also needed to be cajoled into attending community clinics in Felipe Camarão, and special transportation had to be hired for that. Professional tensions between pediatricians and obstetricians as well as between medical and nonmedical staff constituted additional significant barriers to implementing change. The only truly new resource were the community health agents, 16 women and 4 men from the community who were given a limited amount of training and then paid a minimum salary (US $\$ 80$ per month) to work on the project. Although it was frustrating that sufficient funds were not forthcoming to enable the entire Felipe Camarão district to be covered by community health agents, it did at least allow an evaluation of their impact in terms of health promotion.

The other profound methodological difficulty faced from the outset was the lack of any reliable data on the population, necessitating implementing two large community surveys to evaluate the effects of the project. Ideally, these surveys should have been further apart than 30 months, which is too short a period to show change in many health indices. Nevertheless, funding constraints and political difficulties necessitated bringing forward the final evaluation. Differences between the two surveys that did not reach statistical significance might have done so over a longer period of time, and so they should not be regarded as clinically unimportant. Despite these methodological difficulties, reductions in maternal and infant mortality were demonstrated, and the local population increased both its understanding of common health issues and their usage of preventative heath services.

But can these changes be attributed to the ProNatal project? There were inevitably many potential confounders in the complexities of health services in Brazil in the 1990s, many determined by political changes in priorities with the process of municipalization (decentralization) and by interruptions in resource distribution from the federal to state to municipal government levels. There were also some other projects that may have contributed to the changes described in this evaluation. The introduction of community health agents in 1995 was the first stage of the implementation of a family health program (Programa de Saúde da Família) that has subsequently been established in Felipe Camarão. Also, the Kellogg UNI project (6) was active in the west district of Natal towards the end of the intervention period, working to support primary care teams and to train students.

Even while acknowledging these confounders, many changes in women's health in Felipe Camarão can be linked to the ProNatal project. The reduction in maternal mortality can reasonably be attributed to the enhanced antenatal service, with easier access for women in the community and with improved 
identification of high-risk pregnancies. Before the project started, it was quite common for young women from Felipe Camarão not to have any medical care during their pregnancy, and when they went into labor to simply call a taxi to take them to the nearest hospital. Most of the earlier maternal deaths were related to the consequences of uncontrolled hypertension in pregnancy. However, since the establishment of the antenatal services, women with complications such as hypertension are being identified and then treated as a high-risk group. Direct links with the Januário Cicco reference center maternity hospital in Natal have also improved the management of high-risk cases. One other case of pre-intervention maternal death was due to the consequences of an illegal abortion. While such abortions still take place, the availability of family planning services and easier access to tubal ligation has reduced the need for women to resort to such methods. The post-intervention ligation rate in Felipe Camarão was similar to the Brazilian national average of $48 \%$ (7). The increase shown in the proportion of women being sterilized in Felipe Camarão cannot, however, be credited wholly to the project's intervention as there has also been a change in Brazilian law that legalizes tubal ligation outside the perinatal period. The ProNatal project has catalyzed continuing infrastructural changes in maternity services, including the widespread use of a "high-risk" approach to antenatal care, which has resulted in a change in the case mix of women delivering at the Januário Cicco maternity hospital. Women who give birth at the hospital are now highrisk cases only, whereas previously all women from the community were able to present at the hospital for delivery. The introduction of midwife-led antenatal and maternity care, which has been shown to be safe and costeffective in the United Kingdom $(8,9)$, was initially resisted in Natal but is now being accepted for low-risk pregnancies. Nurse-midwives have been introduced at JCMH and at the Felipe Camarão polyclinic, and a midwifery training course has been established at the FURGN Department of Nursing. Similar changes are planned for other parts of Natal and elsewhere in Rio Grande do Norte, involving state and municipal polyclinics.

The reduction in infant mortality was probably related to several of the interventions. An autopsy study (2) undertaken at the beginning of the project in 1993-1995 showed that the majority of the infant deaths occurred after 4 months of age, with malnutrition as a common underlying factor, and respiratory and gastrointestinal infections as the terminal events. These results were similar to other surveys in Brazil (10) and elsewhere in the developing world $(11,12)$. The ProNatal project did not provide any nutritional supplements but instead concentrated on supporting breast-feeding, which should have had an effect on underlying malnutrition and infant morbidity (13). The changes in health behavior reported by the mothers towards their infants with diarrhea and respiratory symptoms indicate both improved illness management at home (14) and earlier presentation for medical services at the community clinics. The improvement in coverage of neonatal BCG could be attributed to increased awareness by the mothers and more efficient neonatal services at the Felipe Camarão centers and at the Januário Cicco maternity hospital. The rise in measles immunization rates is probably due both to the influence of the community health agents $(15,16)$ and to more immunizations being given opportunistically in pediatric clinics in the community. However, this level of coverage is inadequate to prevent measles outbreaks, and further work is needed to improve immunization levels for this vaccine.

The impact of the community health agents was not measured directly, but our two community health surveys provided indirect evidence that the mothers' understanding of common health issues did improve if they had contact with an agent. The health-promoting activity of the agents was inevitably topic based and delivered as a campaign to the community. Experi- ences with community health agents elsewhere in the world $(17,18)$ have shown them to be effective in changing health behavior if targeted towards specific topics (e.g., treatment of malaria (19)) and towards specific client groups (e.g., encouraging hypertensive black men to attend clinics (20)). However, little monitoring and evaluation have been undertaken on national programs utilizing health agents. In Brazil the family health program includes the use of community health agents, and it is being implemented widely across the country after successful experiences in the state of Ceará (21). Our study provides encouraging evidence for the effectiveness of community health agents in Natal, but further impact assessment research is required to evaluate the family health program nationally.

What lessons can be learned from this study that would apply to the rest of Brazil? One lesson is that secondary, specialist services for women and children can be provided in the community and that they can combine effectively with primary care services. Professional barriers, such as those between obstetricians and pediatricians, have to be addressed, and the role of nurses needs to be reevaluated. Although there is strong resistance from medical staff in accepting nurse-led midwifery care, the experience in Natal suggests this opposition can be overcome, and the safety and acceptability of this system are now being evaluated. We have shown that low-risk births are safe in community settings, provided that facilities are adequate and the professional issues have been resolved. However, a residual problem is the system by which obstetricians are paid by the municipal health secretariat for deliveries, which encourages surgical interventions in labor.

The second important lesson from the ProNatal project is that significant reductions in maternal and infant mortality can come from improving access by providing services in deprived communities and from improving awareness and understanding in the population through the use of heath agents. 
A third lesson is that other practical aspects of health care are equally important. These include such things as providing ambulance transport to referral hospitals, providing regular supplies of "essential list" drugs to the municipal community pharmacies, and actually making the promised salary payments to the communitybased health workers. Successfully dealing with these practical concerns, however, is dependent on the political will of the municipal government.

In conclusion, the introduction of a package of community-based interventions in a poor periurban community in the Northeast of Brazil has been associated with significant reductions in maternal and infant mortality over the short to medium term. Low-risk pregnancies have been safely delivered in the community, and more accessible contraceptive services have been provided. Mothers' health knowledge and health behavior have improved, particularly when they have been supported by community health agents. The attitude of professionals working in the community has been transformed, and it is hoped that the experience of medical students, residents, and nurses being trained in the community will reap future benefits.
Acknowledgements. The ProNatal project has involved many different professionals working in Felipe Camarão and at the Maternidade Escola Januário Cicco maternity hospital, and thanks are due to all of them for their dedication and commitment to change. The community health agents have been enthusiastic and effective partners in working with the local community. Julio Cesar in Natal and Sue Bonnell in Bristol deserve special thanks for their help with the data management and analysis. The ProNatal project was supported by the British Council, the British Partnership Fund, CAPES, and CNPq.

\section{REFERENCES}

1. United Nations Children's Fund. A saúde das crianças e mulheres do Rio Grande do Norte. (The health of women and children in Rio Grande do Norte). Natal: Governo do Rio Grande do Norte/UNICEF; 1996.

2. Ramos AMO, Emond AM, Macedo AS, Pollock JI. Project Pro-Natal: Population-based study of perinatal and infant mortality in Natal, Northeast Brazil. Pediatr Dev Pathol 2000;3:29-35.

3. Radford A. The Baby Friendly Initiativesupporting a mother's choice. Paediatric Nurs 1997;9:9-10.

4. Fairbank L, O'Meara S, Renfrew MJ, Woolridge $\mathrm{M}$, Souden AJ, Lister-Sharp D. A systematic review to evaluate the effectiveness of interventions to promote the initiation of breast feeding. Health Technol Assess 2000; 4(25):1-171.

5. Fundação Instituto Brasileira de Geografia e Estatística. Pesquisa Nacional por Amostra de Domicílios/PNAD. Rio de Janeiro: FIBGE; 1995.

6. Kisil M, Chaves M. Linking the university with the community and its health system. Med Educ 1994;28:343-349.

7. Sociedade Civil do Bem-Estar Familiar no Brasil. Saúde da mulher e da criança. Pesquisa Nacional sobre Demografia e Saúde 1996. Rio de Janeiro: BEMFAM; 1997.

8. Turnball D, Holmes A, Shields N, Cheyne H, Twaddle S, Harper Gilmour W. Randomised, controlled trial of efficacy of midwife-managed care. Lancet 1996;348:213-218.

9. Oakley D, Murray ME, Murtland T, Hayashi R, Andersen F, Mayes F, et al. Comparisons of outcomes of maternity care by obstetricians and certified nurse-midwives. Obstet Gynecol 1996;88:823-829.

10. Victora CG, Barros FC, Kirkwood BR, Vaughn JP. Pneumonia, diarrhea and growth in the first $4 \mathrm{y}$ of life: a longitudinal study of 5914 urban Brazilian children. Am J Clin Nutr 1990;52:391-396.

11. Bartlett AV, de Bocaletti MEP, Bocaletti MA. Neonatal and early postnatal morbidity and mortality in a rural Guatemalan community: the importance of infectious diseases and their management. Pediatr Infect Dis J 1991; 10:752-757.

12. de Francisco A, Morris J, Hall AJ, Armstrong Schellenberg JR, Greenwood BM. Risk factors for mortality from lower respiratory tract infection in young Gambian children. Int J Epidemiol 1993;22:1174-1182.

13. Victora CG, Smith PG, Vaughn JP, Nobre LC, Lombardi C, Teixeira AM, et al. Evidence for a strong protective effect of breastfeeding against infant deaths due to infectious disease in Brazil. Lancet 1987;2:319-322.

14. Lira PI, Ashworth A, Morris SS. Low birth weight and morbidity from diarrhea and respiratory infection in northeast Brazil. J Pediatr 1996;128:497-504.

15. Cámara C, Pérez A, Quesada P, Sánchez E. Intervención con agentes de salud comunitarios en programas de inmunizaciones en la comunidad gitana. Aten Primaria 1994;13(8):415-418.

16. Chopra M, Wilkinson D. Vaccination coverage is higher in children living in areas with community health workers in rural South Africa. J Trop Pediatr 1997;43:372-374

17. Frankel S, ed. The community health worker: effective programmes for developing countries. Oxford: Oxford University Press; 1992.

18. Quigley P, Ebrahim GJ. Women and community health workers promoting community health and development. J Trop Pediatr 1994; 40:66-72.

19. Kidane G, Morrow RH. Teaching mothers to provide home treatment of malaria in Tigray, Ethiopia: a randomised trial. Lancet 2000;356: 550-557.

20. Hill MN, Bone LR, Hilton SC, Roary MC, Kelen GD, Levine DM. A clinical trial to improve blood pressure care in young urban black men: recruitment, follow-up and outcomes. Am J Hypertens 1999;12:548-554.

21. Cufino Svitone E, Garfield R, Ines Vasconce$\operatorname{los} \mathrm{M}$, Araujo Craveiro V. Primary health care lessons from the Northeast of Brazil: the Agentes de Saúde Program. Rev Panam Salud Publica 2000;7(5):293-302.

Manuscript received 18 July 2001. Revised version accepted for publication 22 February 2002. 
RESUMEN Objetivos. Evaluar la eficacia de un proyecto de intervención en la comunidad destinado a reducir la mortalidad materna e infantil en un distrito urbano pobre de la ciudad de Natal, en el nordeste de Brasil.

Eficacia de intervenciones en la comunidad para mejorar la salud maternoinfantil en el nordeste de Brasil
Métodos. La intervención, denominada proyecto ProNatal, introdujo en una población geográficamente definida un programa de atención sanitaria comunitaria integrada. Las intervenciones incluyeron el establecimiento de clínicas de atención prenatal en los centros de salud del distrito, la apertura en la policlínica de servicios de maternidad para los partos de bajo riesgo, la creación de una clínica de planificación familiar y otra de lactancia materna, el apoyo de pediatras a las clínicas para niños sanos de menos de 5 años, la creación de servicios ambulatorios y de urgencias pediátricas, y la incorporación de agentes de salud reclutados en la comunidad. Al inicio del proyecto (julio de 1995) y 30 meses después (diciembre de 1997), se realizaron encuestas representativas de la población en las que se usó un cuestionario de salud general adaptado a las condiciones locales. Los datos de mortalidad procedieron de los registros locales y de las autopsias de lactantes y niños fallecidos en el período neonatal.

Resultados. En 1995, de 1195 embarazadas, fallecieron 4 (mortalidad materna de 335/100 000); tres de estas muertes se debieron a problemas hipertensivos y una a perforación uterina tras un aborto ilegal. En 1998 no hubo muertes maternas durante el embarazo ni el parto. En 1993 no hubo partos en la policlínica, pero en 1998 tuvieron lugar allí 946 partos, sin que se produjeran complicaciones graves. El modo del parto, la incidencia de prematuridad y la incidencia de bajo peso al nacer no cambiaron de forma significativa a lo largo del período de estudio. En la encuesta posterior a la intervención, 75\% de las mujeres dijeron haber recibido en el año anterior información sobre la anticoncepción, proporcionada por un médico; antes de la intervención, este porcentaje había sido de 50\%. En un estudio de mortalidad realizado en 1993-1995, la tasa de mortalidad infantil estimada fue de 60/1 000 nacidos vivos. En 1998, según los datos locales recogidos por vigilancia activa, la cifra disminuyó a 37/1 000 nacidos vivos. Las causas de mortalidad infantil predominantes en ambos períodos fueron las infecciones respiratorias y las enfermedades diarreicas. El porcentaje de niños con lactancia materna fue superior a $95 \%$ en ambas muestras, pero la proporción de niños con lactancia materna durante más de 6 meses fue mayor después de la intervención $(41 \%$, frente a $32 \% ; P=0,0005)$. No hubo diferencias apreciables en el uso de las consultas para menores de 5 años, pero las tasas de vacunación aumentaron tras la intervención. Asimismo, se registró un aumento de los conocimientos de las madres sobre las medidas higiénicas básicas, las causas de las enfermedades más frecuentes y el tratamiento de las infecciones respiratorias agudas y la diarrea en los niños; esto fue particularmente notable en las familias visitadas por agentes de salud comunitarios.

Conclusiones. Es posible reducir las desigualdades en la atención sanitaria de las poblaciones urbanas pobres mediante intervenciones en la comunidad, entre ellas el uso de agentes de salud comunitarios. 